\title{
Digital City Projects: Case Studies of Vinhedo and Pedreira, in the State of São Paulo, Brazil
}

Denis Alcides Rezende*

School of Public Service, DePaul University, Chicago, Illionois, USA

\begin{abstract}
Making information and telecommunications available is a permanent challenge for cities concerned with urban planning and development focused on citizens' quality of life and effective municipal management. The objective is to describe the digital city projects in Vinhedo and Pedreira. The Vinhedo project emphasized information and information systems, while the Pedreira project stressed telecommunications based on an open access metropolitan network. The research methodology consisted of action-research case studies covering city hall and local municipal departments and organizations. Both projects resulted in benefits for the municipalities involved, notably modernization of municipal management activities and telecommunications and improved access to public services as a result of the availability of information and increased internet use brought about by digital inclusion. The paper concludes by reiterating the importance of collectively implemented projects when it is accepted that they are instruments that can contribute to municipal management, the implementation of projects for strategic digital cities, decisions taken by public managers and citizens' quality of life.
\end{abstract}

Keywords: Digital city projects; Information systems; Telecommunications resources; Public services; Urban technology

\section{Introduction}

The use of information and telecommunications to provide public services is a constant challenge for cities concerned with planning and developing municipal affairs from the perspective of citizens' quality of life and effective municipal management. Such a challenge requires the involvement of the whole population of the city, including municipal employees and citizens, whether they are workers, students, retired individuals, housewives, councilors or businessmen. Furthermore, the social, environmental, financial and political issues that cities constantly face mean that municipal managers are under pressure to adapt accordingly. At the same time, the participation of citizens in the affairs of a city is an inexorable requirement. One way of addressing these challenges is through collective information and telecommunications planning at both city hall and municipality level, in which systematized information is a prerequisite for municipal organizational and management activities.

The planning of municipal information and telecommunications, like the municipal strategic planning, is one of the tools for managing city halls and towns of unquestionable relevance. It is like that, mainly because of insufficient financial resources to the cities, obedience to the "Lei de Responsabilidade Fiscal", restrictions of the "Estatuto da Cidade", and pressures exerted by citizens and other people interested in the city (social players or stakeholders). These pressures can be minimized by the preparation and implementation of participative strategic planning in the cities, as it can propitiate the collective engagement of the citizens with their wishes and also can decentralize and share the local managers' decisions.

Another problem comes out: the inexistence or inadequacy of municipal information and telecommunications resources of the external and internal environment of some administrations, thus corroborating the difficulties to manage cities and count on the respective participation of citizens in the city management and also in the urban and regional development.

The aim of this study is to describe the digital cities projects in Vinhedo and Pedreira, in the state of São Paulo, Brazil.

In Vinhedo the project emphasized municipal information and is part of a far-reaching project known as Strategic IT planning for a Strategic Digital City, while in Pedreira the emphasis lay on the use of telecommunications to provide an open access metropolitan network and promote the integration of citizens in a single telecommunications environment. Both projects cover the city hall, municipal departments, a self-governing municipal agency and other municipal entities, such as schools, health centers and citizen-oriented municipal information offices.

The reason for that is mainly related to structuring, storage and availability of all information and the sharing of knowledge by means of telecommunications, which surely do not happen overnight and require short, medium and long term action in the cities.

The telecommunications and information planning along with other municipal plans (e.g. Strategic Municipal Planning, Municipal Director Plan, Municipal Multi-Annual Plan, Governmental Plan and others) requires exhaustive practical exercises based on deepseated theoretical fundaments. These exercises are related to dynamic intelligent daily activities of the city halls and to the management actions of the cities. Such activities have to be prepared in an integrated and structured way, where personalized and timely information are essential factors for suitable and participative management of the cities. Evidently, these activities will be more profitable to the cities if they have effective participation of their citizens.

\section{Theoretical Basis}

In order to have the concepts debated and understood some pertinent legislations of each country must be taken into consideration.

*Corresponding author: Denis Alcides Rezende, Researcher Professor, School of Public Service, DePaul University, Chicago, Illionois, USA, Tel: 1 (312) 3950257 E-mail: denis.rezende@pucpr.br

Received July 25 2013; Accepted September 26, 2013; Published September 28,2013

Citation: Rezende DA (2013) Digital City Projects: Case Studies of Vinhedo and Pedreira, in the State of São Paulo, Brazil. J Telecommun Syst Manage 2: 107. doi:10.4172/2167-0919.1000107

Copyright: (C) 2013 Rezende DA. This is an open-access article distributed under the terms of the Creative Commons Attribution License, which permits unrestricted use, distribution, and reproduction in any medium, provided the original author and source are credited. 


\section{Information and information model}

For initial conceptualization, a piece of information is any datum considered or worked out. It can be understood as a datum with a meaningful value attributed or added to it and having a natural and logical sense for those who use that piece of information. It can be defined as something useful [1]. Information to be useful for decisionmaking should have the following characteristics or premises: not to be abstract, not to have verbs, to be different from documents, programs, files and things alike.

Information and its respective systems perform fundamental functions in the city halls and towns, presenting themselves as a strategic resource to plan and manage city halls and towns in an intelligent, competitive, participative manner. To ensure this strategic connotation to information the organization usually goes through an evolving cycle in stages, such as: initiation, contact, control, integration, data administration, and maturity [2].

The information acculturation process in the city halls and towns can be ease and effective if public managers and residents (clients or information users) are participative, aware and thoroughly engaged in the utilization of information technological resources. The strategic information supported by information technology may occur in an evolving way, where information systems can be classified in various manners [3].

Information has a highly significant value and can stand for great power for those who own it, either a person or an organization. The information valorization process comprises some logical phases and steps [4]. At least three steps are fundamental to add value to information: getting to know, selecting and using information. A badly prepared selection may cause major damages in the use of information.

The information model describes all the necessary pieces of information for management of city halls or towns [1]. Such pieces of information can be structured in levels or types, i.e, strategic, managerial and operational information. They can be distributed according to their respective organizational functions or public issues. In the information model document it is described the strategic pieces of information (in a macro-related way with the external and internal environment), the tactic and managerial pieces of information (grouped and synthetized) and the operational pieces of information (in detail or analytical). Also, the information model may contain integrated information of the kinds: conventional (trivial), personalized and timely.

All and any peculiar or specific information can be named personalized information, either being a natural or legal person or a differentiated product or service. It may also be regarding a single characteristic of a citizen. All and any information of unquestionable quality, however, anticipated can be named timely information [3].

\section{Information system and information technology}

A system of information proposes as an output, the result of data processing or of resources to be transformed, for instance, information, being computational resources information or not [5]. The information systems - which have as a major objective the aid to city halls in their decision-making processes and whose focus must be addressed to municipal services - will be able to significantly contribute to solve many municipal problems; in the extent they effectively generate timely and personalized information. They have to be seen as tools to determine differential factors of the city hall [1] and are defined as systems of human and technical components that accept, store, process, produce and transmit information, and can be based on any combination of human engagement, methods and information technology [6]. They are the ways by which people and organizations put together, process, store, use and disseminate information [7]

An information system can have operational effectiveness, large impact on municipal strategies and on the success of city halls, benefiting them, the citizens or any private individual or group that interact with municipal systems [8]. The information system benefits are widely reported and justified in the pertinent literature and articles. They should present themselves as instruments for generating solution factors of the municipal problems [9]. To facilitate these solutions, the information systems should be integrated and have an interdependent relation with the involved sub-systems, which chiefly leads to information exchange amongst them. Such integration can also be named systemic vision, systemic approach, forest view, municipal gear, information synergy and harmonic set of organizational functions. This way, the information systems can show themselves as information sub-systems or organizational functions, divided into: production or services; commercial or marketing; material or logistics, financial, juridical-legal, human resources and their respective modules [3] Only through the integration of these sub-systems it will be possible to produce timely and personalized information.

The levels of information and decisions in the city halls can obey the pattern-hierarchy existing in most organizations (organizational pyramid). These levels are known as strategic, tactic and operational. The kind of decision made in each level requires different degree of information and data aggregation. The various decision levels call upon different information in their several types of resulting products, such as screens, reports, etc. Practically, there is not any rigid classification, what allows people and administrations to classify their systems in different ways. All in all, the IS can be ordered in operational, managerial and strategic $[8,9]$. The main difference amongst information systems in such a classification lies on the way the information is presented to users.

The operational information systems provide detailed information. The managerial information systems make available grouped or synthesized information. The strategic information systems enable the comparison of information both inside and outside the city hall environments, also between other cities, and eventually generate some indicators and knowledge. Another way to classify information systems is as for the city hall scope. So considered, there are systems at personal, group (or departmental), organizational, and inter-organizational levels in which the global systems of information are framed, involving several city halls of various towns [10].

The Information Technology (IT) or Information or Communication Technology (ICT) can be conceptualized as computational and technological resources for data storage, generation and use of information. It is based on the following components: hardware and its devices and peripherals; software and its resources; telecommunications systems; data and information management $[3,8,11]$. It can also be defined as telecommunications and computing technologies that supply automatic means and information handling, encompassing tangible hardware and intangible software [6] and telecommunications networks [7].

When information technology is applied in public administration (in the spheres of federal, state or municipal), it is called electronic government (e-gov). Thus, e-government can be seen as the application of the resources of IT or ICT in public management and policies of federal organizations, state and local, including the city and municipal organizations. This may involve actions of government to government 
or government to society and its citizens (and vice versa), providing public information in an electronic media format [12]. Electronic government (e-gov) promotes efficient and cost-effective government; facilitates more convenient government services; allows greater public access to information and makes government more accountable to its citizens [13]. Governments around the word have created websites that enhance citizen convenience in various projects within different levels of public services [14]. E-gov involves the creation, development and interlinking of a variety of social, institutional and technological ecologies to deliver services which are perceived as legitimate, innovative, useful and welfare enhancing [15]. The use of modern information and communication technologies, especially Internet and web technology, by a public organization to support or redefine the existing and/or future (information, communication and transaction) relations with 'stakeholders' in the internal and external environment has a tendency to create added value [16]. The uses of information technology in the public sector, covers a broad range of managerial issues: from high-level strategy to detailed tactics; from the technicalities of data flows and process mapping to the politics of e-government [17]. The strategic use of ICT, in and around public administrations, is for the purpose of creating a 'wired' or 'digital' government. Ideally, a wired government is more focused on and responsive to societal needs, and makes governments more efficient and democratic [18].

\section{Information planning and information technology planning}

The Municipal Information Planning is a project that formalizes the necessary information for city hall and town management and, as a result, it plans the municipal information systems and their respective needs of information technology assets and of human resources [1].

The Information Technology Strategic Planning (ITSP) is a dynamic and interactive process to, strategically, tactically and operationally, structure the organizational information, the information systems, the information technology (and their resources: hardware, software, telecommunications systems and data and information management), the people involved, and the required infra-structure for assisting all decisions, actions and respective processes of the organization $[1,11,12]$.

The alignment between the ITSP and the municipal plans and planning can be built from the satisfactory vertical, horizontal, transversal, dynamic and synergetic relations of the municipal functions and of the IT resources. Such alignment can promote the adjustment or strategic and operational suitability of available technologies in the entire city as a municipal management tool put together by quality concepts, productivity, effectiveness, continuity, competitive intelligence and municipal intelligence $[1,19]$.

\section{Digital city}

The concept of digital cities regards the gathering and organization of digital information to provide some information room such that their residents and visitors can interact among themselves [20]. It is the digital network environment created in the territory, which interlinks advanced technological systems in order to connect public services, assets, brands, schools, third sector organizations, enterprises, micro and macro people communities, making information available in several orders and patterns aiming to develop the information society potentialities and transform the citizen into actor and protagonist of a virtual reality [21].

A digital city can be defined as a city that collects and organizes digital information about itself, provides public information for people to interact with each other over the internet [22] and can be lived in by digital citizens, who are able to participate in an online society [23].

The cities concern about physical changes to enable ICTs technical conditions and to ease the functioning of digital cities with their technological resources and respective conceptual, cultural and urban impacts $[24,25]$. The cities require new elements for their organization and reproduction or the urban area, providing the shrinking of distances like extended cities by including the use of ITCs [26] or like cities in network $[27,28]$.

For Lemos [29] science and technology become important for the urban area development. The challenges of the urban area should go beyond geographic boundaries in the virtualization of the cities or in the cyberspace that can bring the possibility of distance annulation amongst the dwellers of a city, even if the distance annulation be just symbolic, as it is through digital communication [30]. The cities change due to the advent of new communication technologies in a continuous move towards "de-territorization" of symbolic worlds and the breakup of frontiers between the ancient and modern, between local and global, between written and audiovisual culture, leading to fast urban modernization processes in adequate environment for digital cities [31]. The exchange of telematics information help people get free from time-space confinement, traffic and other difficulties of physical places [32]. It doesn't come to evidence the replacement of the real city with the virtual one; the focus is on the enlargement of access for the citizens to activities of collective intelligence and on the occupation of the cyberspace, as in the geographic city, fulfilling thoroughly the citizens' needs [33].

In the context of telecommunications, digital cities are also called "information highways", with a set of web applications, IP applications, services and equipment that provide citizens with a constantly present, ubiquitous, pervasive environment that not only is present everywhere at the same time but also spreads itself, infiltrates, penetrates and is spread. Digital cities, which are also known as, amongst other things, cybercities, virtual cities, electronic cities and intelligent cities, represent projections of cities into the digital world [34].

Strategic digital city can be understood as an application of information technology resources in the management of the municipality and also in the availability of information and services to residents. It is a far-reaching project if compared to just offering internet to citizens through telecommunications conventional resources. It goes beyond digital inclusion of citizens in the world network of computers, once such ample projects encompass information systems for municipal management and citizens, public services for the community and also municipal safety systems [1].

Brazilian government has been creating special programs to enhance and spread information technology and telecommunication infrastructure, disseminate access to the Internet, and stimulate webbased public services [35].

\section{Research Methodology}

The research methodology employed here comprises an approach of applied work nature to a circumstantial reality, emphasizing the inductive method enhanced by professional experience achieved by the authors-researchers, both in advising projects for city halls and in academic projects for degree, master and doctoral classes. It partially takes exploratory research concepts regarding documental and bibliographic raising [36,37].

The research methodology consisted of action-research case studies 
covering city hall and local municipal departments and organizations. It was applied work because it generated new useful knowledge for science breakthrough and for practical checkup addressed to solution or facilitation of problems concerned to the planning of municipal information with the participation of the society (municipal servers and citizens) and of the management of a city [38].It has put together other approaches explained by the eclecticism and integration of inseparable methods $[39,40]$.

The study sample consisted of two cities, Vinhedo and Pedreira, in metropolitan Campinas, in the state of São Paulo, Brazil. Vinhedo has 60,000 inhabitants, and Pedreira 45,000.

The materials and methods utilized are pertinent to available resources of research-action case studies. Forms were used for data gathering (planning, organization, diagnoses, analyses and debates), information tab, follow-up, controlling and documentation. Finally, it was carried out assessments of the procedures and actions performed. The research also used several investigative techniques, such as personal observation, questionnaires, field survey, semi-structured interviews, meetings and seminars, which were attended by common citizens, public managers, suppliers, and public service providers. That way, the surveyors were, in a cooperative and participative way, fully engaged in the process. All these features and documents used contributed to the achievement of the objective of this article to describe the digital city projects in Vinhedo and Pedreira.

The action-research protocol was an integral part of the methodology used in the project and had phases and subphases as its variables. The observation unit included municipal employees (managers and technicians) and citizens (workers, students, retired individuals, housewives, councilors and businessmen).

The project in Vinhedo was developed between August 2009 and July 2010 and has been in operation since 2011, when it was implemented. The project in Pedreira was developed from September to November 2006 and has been in operation since 2006.

\section{Vinhedo, Strategic Digital City Project}

The project is part of a far-reaching project known as Strategic IT planning for a Strategic Digital City (SITP/DC) and covers the city hall, municipal departments, a self-governing municipal agency and other municipal entities, such as schools, health centers and citizen-oriented municipal information offices.

To carry out the project a methodology was defined that documented parts, phases, subphases, products and approval points. The different parts and phases were: organizing, communicating and training (phase 0); reviewing strategic municipal planning; planning municipal information; evaluating and planning information systems; evaluating and planning information technology; evaluating and planning human resources; establishing priorities for and costing the implementation of the SITP/DC project; implementing the SITP/DC project; and managing the SITP/DC project [1].

\section{Organizing the project and reviewing strategic municipal planning}

The first activity needed to develop the SITP/DC project was the preliminary organization (phase 0 : organizing, communicating and training). This consisted of tasks that were carried out before and during the actual development of the project and included the following subphases: learning about the area where the SITP/DC project would take place; defining the project concept; defining the objective; adopting a methodology; defining the multidisciplinary team (or project committee); making people aware of the SITP/DC project; training those involved; choosing management tools for the SITP/DC project; and drawing up work plans for the different phases and subphases of the SITP/DC project. This phase was carried out at the same time as the Manage SITP/DC phase (which also extended throughout the project).

The fact that Vinhedo does not have a strategic municipal plan made it difficult to carry out the necessary subphases. However, the 2009/2012 government plan partially describes the analyses carried out in the municipality, the main problems and challenges, the municipal directives, the main objectives, the strategies and the main actions taken by the City of Vinhedo.

\section{Planning municipal information}

This phase covered public functions or areas under municipal responsibility: administration; agriculture; science, technology and innovation; commerce; culture; education; sports; finance; government; housing; industry; legal affairs; leisure; environment; works; planning; health; sanitation; safety; municipal services; social; transit; transport; and tourism.

In all, 1331 lists of municipal activities were drawn up covering the main activities carried out by the fifteen municipal departments and one self-governing municipal agency (Vinhedo Superintendency for Water and Sewers - Sanebavi). The municipal activities can also be viewed as processes involving tasks in each municipal department and all the other municipal entities.

Municipal information models with 18,200 items of operational and management information were prepared for the whole municipality, city hall and the respective municipal entities. At the request of the project management committee, all the operational and management information was documented (the former in detail and the latter at aggregate level); strategic information (related at a macro level to the environment inside and outside the city hall and municipality) was not documented. Repeated information or information with the same content was not excluded from the modeling.

The phase Identify Municipal Knowledge will be carried out in the second version of the SITP/DC project together with the evaluation and planning of municipal knowledge systems.

\section{Evaluating and planning information systems}

All the municipal information systems were identified and described in specific documents, which stated that all the systems needed improvements, i.e., that they were inadequate for the municipality's needs. The evaluation and summary covered 407 systems, broken down as follows: 20 systems from a service provider; 18 from a range of suppliers; 70 from governments and public bodies; 214 from Microsoft $^{\mathrm{mix}}$ and 85 manual systems.

The municipal information systems were evaluated and planned taking into account the different areas under municipal responsibility, municipal activities, the information models produced and discussions held with the public in Vinhedo. In all, 140 proposed municipal information systems covering city hall, the municipal departments, one municipal agency and the remaining municipal entities were evaluated, represented schematically, described and planned. All the systems were confirmed with the staff in the respective municipal departments. To do this, a table of the proposed information systems containing the name of the municipal department and the number of systems was drawn up. The number of systems for each department was as follows: 
administration, 23; agriculture, 8; science and technology, 2; commerce, 3 ; culture, 6; education, 14; sports, 2; finance, 10; government, 5; housing, 5; industry, 1; legal, 2; leisure, 2; environment, 4; works, 2; planning, 5; health, 15 ; safety, 4 ; municipal services, 8 ; social, 8 ; transit, 1 ; transport, 5 ; tourism, 4 ; and sanitation, 1 .

All the systems will be supplied by companies specializing in system design, development and maintenance in a tender process. None of the information systems will be developed by the in-house team. In parallel, 26 suppliers of municipal information systems that could meet the requirements for the proposed information models and systems were selected and evaluated.

Completing the municipal information systems planning phase, the project management committee determined that systems intended for public functions or the social, financial and health areas. It was also determined that there should be a single database, i.e., that no redundancy should be permitted in terms of municipal or city hall data, citizen's data or any other standard data.

\section{Evaluating and planning information technology}

All the information technology resources in the municipality were identified and analyzed. This included hardware, software, telecommunications systems and data and information management.

All the software used in Vinhedo was identified, described and evaluated as part of the information technology inventory. A total of 692 pieces of software distributed as follows were evaluated: Windows - 325; MS Office - 320; BR Office - 5; Corel Draw - 16; Photoshop - 7; AutoCAD - 17; Topevn Topografia - 1; and Windows Server - 1. All the hardware used in Vinhedo was also identified, described and evaluated. A total of 458 items of hardware (28 servers and 430 computers) were evaluated.

The telecommunications facilities were identified, described and evaluated to provide an overall view of the telecommunications sites and hardware and software. The survey of the data and information management systems revealed that data backup and recovery is performed manually on servers. Access control and system browsing control is done at departmental and personal level.

City hall does not define contingency plans or plans for logistics, security, auditing or other IT policies, and there are no IT rules covering technical operational standards and norms for software, documentation or project management. The table summarizing the IT resources reflects the detailed breakdowns for the previous items.

The documentation relating to software, hardware, telecommunications systems, data and information management and all the necessary details is constantly updated and recorded in the Information Technology Unit.

Strategies, policies, norms and technical operational standards as well as the configuration of the IT components were partially defined and will be aligned with Vinhedo's objectives and completed when the municipal information systems are implemented.

The configuration of the telecommunications systems for Vinhedo will be completed when the municipal information systems are implemented as these determine what the appropriate configuration should be. A specialized telecommunications company is developing a telecommunications project with three elements to carry electronic data traffic related to the following areas: internet (for the public), municipal information systems (for municipal managers and the public) and public safety in the municipality. The premise on which the telecommunications systems in Vinhedo are based is that of the "digital city". The project also considered the possibility of expanding the telecommunications and data and information management systems.

The current information technology team is "small" and not suitably qualified. Of the four technicians who support the IT facilities in all the municipal departments, one passed a civil service examination (in a field other than information technology), two hold positions of trust and one is a contractor.

The physical facilities are inadequate and constitute a serious risk for the IT systems.

The IT unit's strategies should be aligned with the municipality's objectives and strategies. They will be defined when the new IT unit (including people and facilities) is defined and implemented.

The IT unit's policies define the general rules governing the unit's management activities and involvement in the municipality as well as its detailed procedures. They are geared toward "what" to do in terms of general guidance or parameters. Like the IT unit's strategies, the policies must be aligned with the municipality's objectives and strategies. The IT policies will be defined when the new IT unit (including people and facilities) is implemented.

The IT unit's technical operational norms and standards are geared toward "how" to do things. They cover manuals, work forms, standard layouts for software documentation and related legal issues. They may also be aligned with a particular quality tool or technical standard chosen by the municipality. Like the IT unit's strategies and policies, they must be aligned with the municipality's objectives and strategies. The IT standards will be defined when the new IT unit (including people and facilities) is implemented.

The management model for the IT unit must be aligned with the municipality's objectives and strategies. The model will be defined when the new IT unit (including people and facilities) is implemented. It was recommended that an IT committee made up of IT technicians and municipal employees should be set up and that the committee should meet regularly to define activities and priorities for IT services and resources based on IT strategies, policies and technical operational standards and norms.

The IT unit should include a suitably qualified manager in addition to the technical team. The first proposal put forward for municipal management was a Municipal Department of Science and Technology. As an alternative, an IT directorate reporting to the Municipal Administration Department was proposed. The main functions that would be carried out by the IT unit were planning and implementing activities related to municipal IT and information systems resources; defining objectives, strategies and actions for the IT unit and ensuring that these are achieved or completed; defining technical operational policies, standards and norms for the unit and for IT resources; and responding to the needs of IT and information system users in the various municipal departments. The team proposed for the IT unit included the following members (all of whom would preferably have passed a civil service examination): IT director; IT manager; information system support analyst; and IT assistant(s). Optionally, when IT systems are developed internally, the IT unit should also include the following staff (all of whom would preferably have passed a civil service examination): information systems development analyst(s); database analyst; and information systems programmer(s).

The proposed facilities for the IT unit include a suitable building where the necessary technology can be installed in a secure environment 
suitable for hardware (computers, printers and peripherals), software (programs and utilities), telecommunications (the connection between hardware, software and systems) and data and information management (data backup and recovery, access control and information systems browsing control).

\section{Evaluating and planning human resources}

The study covered all the positions in city hall rather than only those functions or positions related to municipal information systems and IT resources. The management skills required encompassed three major competencies: people or human resources; municipal processes, activities or projects; and various resources related to technology, finance, material, time etc. "Non-managers", or technicians, required three main skills: technical skills; skills related to municipal activities; and behavioral (soft) skills. "Assistants" skills satisfied the requirements of the particular project or municipal activity they were working on.

All the municipal employees using the existing information systems were identified.

It was decided by the city hall to hire the Brazilian Institute of Public Administration (IBAM) to evaluate and plan skills and competencies, review the organizational structure and evaluate recruitment, selection and training processes.

\section{Assigning priorities to and costing the implementation of the SITP/DC project}

The first criterion focused on the 2009/2012 government plan. Using the criteria defined by the municipality, the following priorities were established by the project management committee: the telecommunications project (an information highway covering three telecommunications areas: internet for citizens; information systems for managers and citizens; and public safety in the municipality); implementation of a single database (municipal information systems); an information system for municipal social assistance and welfare; a public finance system; and a municipal health information system.

The funds needed to implement the project are being defined in the relevant documents in accordance with the existing multi-year plan. Projects are also being prepared to evaluate the possibility of obtaining funding from the Federal Program for the Modernization of Tax Administration and Management in Basic Social Sectors (PMAT). The possibilities for public-private partnerships will be investigated.

To analyze the impacts of the SITP/DC project, a list of positive and negative points and alternatives or recommendations for the following impacts was drawn up: political, cultural, behavioral, technological, budgetary, legal, performance, organizational and management. All the project impacts are being described and managed by the project management committee with a view to finding alternatives or ways to minimize them.

The strategies and policies for the financial-economic plan and return on investments were aligned with the 2009/2012 government plan. They will subsequently be aligned with municipal objectives and strategies and with the IT unit strategies and management model. The funds needed to implement the project are being defined in the relevant documents in accordance with the existing multi-year plan and, if required, with PMAT and public-private partnerships.

The financial/return on investments plan or cost-benefit, risk and feasibility analysis were drawn up specifically for each phase or activity in the project implementation. The funds needed to implement the project are being defined in the relevant documents in accordance with the existing multi-year plan and, if required, PMAT and public-private partnerships.

\section{Implementing the SITP/DC project}

The work plans or timetables were prepared and broken down into different internal and external activities to implement the project. The plans took into account the priorities that had been defined and emphasized the development of the alternatives presented; acquisition of information system solutions and IT resources; outsourcing of activities; implementation, adjustment, or maintenance of systems; and implementation of solutions, among other things.

The plans for priority actions and actions in progress were established by the project management committee, the most notable being the telecommunications project (an information highway covering three telecommunications areas: internet for citizens; information systems for managers and citizens; and public safety in the municipality); implementation of a single database (municipal information systems); an information system for municipal social assistance and welfare; a public finance system; and a municipal health information system.

In parallel with the invitation to tender for priority municipal information systems, three other tender processes will also be held: telecommunications engineering projects for optical fiber, radio aerials and other communications equipment for the whole municipality; implementation of the telecommunications engineering project; and management of the telecommunications systems together with the municipal information systems.

\section{Managing the SITP/DC project}

Project management activities included setting up the teams defining the methodology and phases; training those involved; planning and controlling activities; project follow-up; communicating project activities; evaluating products or results; and other relevant activities. Participative management was adopted as the project management model, PMBOK/PMI ${ }^{\mathrm{mt}}$ as the method and Excel ${ }^{\mathrm{mm}}$ as the project management tool.

The aim in publicizing the project was to ensure that all the municipal employees and citizens of Vinhedo were committed to and involved in the project.

The project is managed by a multidisciplinary project management committee. In addition to the project management committee, 5 municipal employees were directly involved in the project, 27 others were members of the municipal affairs team, 3 represented the IT team and 170 employees from all the municipal departments also took part.

The project documentation, together with the glossary of terms and final report, was intended to provide a formal written record of the project. It also afforded a means of communicating with those directly and indirectly involved in the project. All the project documentation is kept in magnetic form and hardcopy and stored in folders in the project management committee room. Documents related to hardware, software and other technological resources are stored in the IT unit.

The project was repeatedly presented to and evaluated and approved by those involved, including municipal employees and the citizens of Vinhedo.

\section{Pedreira, Municipal Digital City Information Highway Project}

The project was intended to provide the municipality of Pedreira 
with a master plan for the construction of a municipal information highway to guide it in the development of a metropolitan network for a digital city and e-government services through the construction of telecommunications environments. The project covered health, social assistance, safety, education, public works and planning, as well as the citizens of Pedreira themselves.

It emphasized the importance of telecommunications networks in meeting the needs of municipal managers, providing free internet for the public and making access to e-government services available to businesses [34].

\section{Organizing the project and reviewing municipal planning}

To implement the project, the physical locations where the municipal information highway would be implemented were selected using a concept, methodology and formal team.

The municipal information highway project was related to the programs in the 2006/2007 multi-year plan and to actions specified in the Pedreira 2003/2004 government plan.

\section{Evaluating and planning municipal information and information systems}

Planning of municipal information and information systems was not prioritized. In other words, information and the associated information systems were evaluated and suggestions made after the IT and telecommunications planning.

Once the municipal information highway had been implemented and the associated telecommunications networks were available, the information systems were analyzed with a view to interconnecting them.

\section{Evaluating and planning information technology}

In the municipal information highway project, priority was initially given to the evaluation and planning of telecommunications systems. Next in priority were the other elements of IT: software and utilities; hardware and peripherals; data and information management; and the respective contingency, logistics, security and audit plans and other IT policies.

The network implemented in Pedreira was an open access Metropolitan Area Network (MAN). Open access MANs are telecommunications networks that integrate a complete municipality in a single telecommunications environment. This type of network can boost economic and social development and have a positive effect on, among other things, a country's productivity and ability to innovate. In Brazil, municipal information highways have been used to make digital cities feasible. Open access MANs are the telecommunications infrastructure that interconnects public buildings and provides the public with residential broadband connections, promoting digital inclusion. This type of telecommunications environment favors, among other things, the development of digital, or intelligent, cities, as open access MANs allow the whole city, including its citizens, to be integrated in a single telecommunications environment.

The project implemented in Pedreira used a hybrid architecture based on optical fiber and wireless. The network consisted of $40 \mathrm{~km}$ of monomode 24-fiber optical fiber cables, three optical fiber rings, one optical fiber spur and $13 \mathrm{Wi}$-Fi IEEE 802.11a radio links operating at $5.8 \mathrm{GHz}$. There are 24 wireless cells distributed throughout the municipality and another 25 being installed. The cells operate at 2.4 $\mathrm{GHz}$ and use the IEEE $802.11 \mathrm{~g} / \mathrm{n}$ Wi-Fi protocol

\section{Assigning priorities to, implementing and managing the municipal information highway project}

When assigning priorities to, costing and implementing the Pedreira municipal information highway project, priority was given to telecommunications. After this, the costs of the municipal information systems were evaluated and prioritized accordingly. The first criterion related to the 2004/2008 government plan, and the second to the possibility of obtaining funding from federal government.

The implementation of the municipal information highway project prioritized the preparation of timetables-broken down into internal and external activities-for the invitation to tender for the telecommunications systems and the acquisition and implementation of these.

Project management activities included setting up the teams, defining the project, planning, controlling and following up project activities, evaluating project products or results and other relevant activities. The tools used included Excel ${ }^{\mathrm{Tx}}$ and project management documentation, techniques and software.

\section{Discussion and Conclusion}

Municipal planning, whether it is strategic, information or telecommunications planning, requires the participation of citizens and the involvement of municipal managers to expand social, urban and regional development. It can also contribute to municipal management by making planned information and the associated telecommunications available. From the point of view of citizen participation, municipal planning can also promote the practice of citizenship as citizens take part in the planning, structuring, storage and release of information for their use and benefit. This is particularly true insofar as the increase in telecommunications-based public services is concerned. Municipal planning also allows cities to extend their communications, education and social development activities. This is possible because a large number of cities face constant social, environmental, financial and political challenges promoting effective municipal management and an adequate quality of life for their citizens. In both the projects described here the public took part together with municipal managers to minimize the constant challenges faced by the municipalities.

Undoubtedly, the municipal information and telecommunications strategic planning, like the municipal strategic planning, can become an inexorable participative instrument of management of city halls and cities. With the right modeling, planning and availability of information and municipal services, it makes possible the breakthroughs in the citizenship building in the public space, in the municipal democratic governability, in the transparency of management and in the urban and regional development of the cities.

The objective of describing the digital cities projects in Vinhedo and Pedreira has been achieved as details of the planning of the information systems and telecommunications in these municipalities have been presented. Both projects covered the city hall, municipal departments and other municipal entities, such as schools, health centers and citizen-oriented municipal information offices. Most notable about the planning was that municipal managers, municipal employees and the public, whether they were workers, students, retirees, housewives, councilors, businessmen or other social actors, all took part.

In Vinhedo the first impact was the elaboration of 1,331 Lists of Municipal Activities containing the main activities or processes of elaborated municipal tasks. It was a challenge because the City Hall had not documented its activities in a structure organized as the science 
of administration asserts. However, further, the people involved were prepared and motivated to participate of the Project MIP/IT of Vinhedo and to elaborate, mainly, in a collective way, the models of information, the evaluation and the planning of all municipal information systems.

The social players involved propitiated the integration of technological resources with the social participation in a democratic popular experience, and together, local managers and citizens, by means of an organized project, could model 18,200 pieces of managerial and operational information for all the city, City Hall and respective units. Such information formalizes their wishes, interests and, mainly, their personal needs, let us say, it was addressed to the city reality. Beyond these pieces of information, they could plan and prioritize 140 municipal information systems proposed.

In Pedreira an important benefit of the municipal information highway was that it made the convergence of infrastructure and the democratization of the different forms of communication and information distribution possible. The information highway also produced a unique distribution environment by allowing: the flow of multimedia data, including medical images, videoconferencing, distance education, administrative data and educational data; the provision of services to the community/commerce/industry; and the creation of technology centers.

Also of note are the advantages for the citizens of Pedreira, who have free communal access to public services on the internet. The work of municipal employees is made easier through the use of video conferencing and telephone technology connecting all the public services and municipal departments. Safety in the city is improved because the telecommunications network has allowed digital camerabased surveillance systems connecting the civil and military police, municipal guards and firefighters to be set up. More than 4600 homes in Pedreira already have free internet access, and this figure is expected to reach $100 \%$ of the population within a year. A Knowledge Connection and web-based e-Gov solution are also being implemented.

Comparing the two municipalities, it should be stressed that the Vinhedo project emphasized information and information systems, while in Pedreira the emphasis lay on telecommunications and the internet. Despite the different methodologies used, both projects resulted in benefits for the municipalities, notably modernization of municipal management activities and telecommunications and improved access to public services as a result of the availability of information and increased internet use brought about by digital inclusion. The projects also boost the local economy through direct and indirect services provided by companies based in the municipalities.

In particular, to other cities, the results achieved describe, by means of different methodologies, the phases, sub-phases, activities, approval points and resulting products, and formalize their respective challenges and difficulties. All these challenges, difficulties and findings can be implemented in similar digital cities projects. Also, can facilitate communications between the citizens and govern to expand credibility, trust and equality, promoting accountability, transparency, and democracy.

Evidently there were many difficulties throughout the elaboration of the phases, sub-phases and tasks to plan in a participative way the information and telecommunications of the city. However, such difficulties were day by day and collectively overcome, either by the local administration or by the citizens and organized civil society that took part in the realization of the Project MIP/IT of Vinhedo.

Regarding the contributions of this work, they report the practical viability of the project developed and of the execution details of its methodology. Such contributions are addressed to the academy, to the participant city of the case study, and to other cities. To the academy, it is highlighted the project elaboration methodology in a participative way, putting together interests of local managers and of citizens.

The case study described can facilitate other researches applied to cities to understand and suggest alternatives for their challenges coming from urban and regional planning and development, as well as, from public management that involves citizens, municipal servants, local managers and other players interested in the city researched and other surrounding cities. To the city under consideration this work contributed to the elaboration and further implementation of a vanguard project which will display information for decisionmaking, either to its local managers or to its citizens, allowing broader understanding on equals or similar projects. This work also contributes to the establishment of analogies among the cities.

There weren't restrictions as for the access of people to the project, nor to information or telecommunications of the city and of the City Hall. The main restriction to this work had to do with the research methodology itself as it reduces pertinent analyses and considerations to a single city, so not expressing the reality of Brazilian cities.

The conclusion reiterates the importance of a project methodology, collectively implemented by municipal servants, local managers, and citizens; and accepts it as an instrument to, effectively; contribute in the management of cities and in the implementation of strategic digital city projects. With the effective implementation of this kind of project; the democratic public space; transparency; effectiveness and governability of municipal services; the social, urban and regional development can be widened and, as a result, the quality of citizens' life can also be better.

\section{References}

1. Rezende DA (2012) Planejamento de estratégias e informações municipais para cidade digital: guia para projetos em prefeituras e organizações públicas. Atlas, São Paulo, Brazil.

2. Nolan RL, Seger KN (1993) Note on information technology and strategy Harvard Business School, Boston, USA

3. Rezende DA, Abreu AF (2013) Tecnologia da informação aplicada a sistemas de informação empresariais: o papel estratégico da informação e dos sistemas de informação nas empresas. Atlas, São Paulo, Brazil.

4. Weitzen HSO (1991) O poder da informação: como transformar a informação que você domina em um negócio lucrativo. Makron Books, São Paulo, Brazil.

5. O'Brien JA, Marakas GM (2011) Introduction to Information Systems-Loose Leaf. McGraw-Hill, Columbus, USA.

6. Heeks R (2001) Reinventing government in the information age: international practice in IT-enabled public sector reform. Routledge, London, UK.

7. Ward J, Peppard J (2002) Strategic planning for information systems. John Wiley \& Sons, New York, USA.

8. Stair RM (2007) Principles of information systems: a managerial approach Delmar Cengage Learning, USA.

9. Laudon KC, Laudon JP (2011) Management information systems: managing the digital firm. Prentice Hall, New Jersey, USA.

10. Kroenke D (2011) MIS Essentials. Prentice Hall, New Jersey, USA.

11. Turban E, Mclean E, Wetherbe J (1996) Information technology for management: improving quality and productivity. John Wiley and Sons, New York, USA.

12. Lederer AL, Mahaney RC (1996) Using case tools in strategic information system planning. Information Systems Management Journal 13: 47-52.

13. Bhatnagar S (2004) E-government: from vision to implementation. Sage Publications, New Delhi, India. 
Citation: Rezende DA (2013) Digital City Projects: Case Studies of Vinhedo and Pedreira, in the State of São Paulo, Brazil. J Telecommun Syst Manage 2: 107. doi:10.4172/2167-0919.1000107

Page 9 of 9

14. West DM (2005) Digital government: technology and public sector performance. Princeton University Press, New Jersey, USA.

15. Navarra DD, Cornford T (2005) ICT, innovation and public management: governance, models \& alternatives for e-government infrastructures. European Conference on Information Systems (ECIS), Regensburg, Germany.

16. Bekkers VJJM, Homburg VMF (2005) The information ecology of e-government: e-government as institutional and technological innovation in public administration. IOS Press, Washington DC, USA

17. Heeks R (2005) Implementing and managing eGovernment: an international text. Sage Publications, London, UK.

18. Homburg V (2008) Understanding e-government: information systems in public administration. Routledge, London, UK.

19. Henderson JC, Venkatraman H (1993) Strategic alignment: leveraging information technology for transforming organizations. IBM Systems Journal 38: $472-484$.

20. Besselaar PVD, Beckers D (2009) Demographics and sociographics of the digital city. Community Computing and Support Systems, Social Interaction in Networked Communities, Springer-Verlag, London, UK.

21. Guerreiro EP (2006) Cidade Digital: Infoinclusão Social E Tecnologia Em Rede. Senac São Paulo, São Paulo, Brazil.

22. Ishida T (2004) Activities and Technologies in Digital City Kyoto. Lecture Notes in Computer Science 3081: 166-187.

23. Mossberger K, Tolbert CJ, McNeal RS (2008) Digital Citizenship: The Internet, Society, and Participation. MIT Press, Cambridge, USA.

24. Atkinson RD (1997) The Digital Technology Revolution And The Future Of US Cities. Journal of Urban Technology 4: 81-98.

25. Shiode N (2000) Urban Planning, Information Technology, and Cyberspace. Journal of Urban Technology 7: 105-126.

26. Firmino RJ (2004) Building the Virtual City: The Dilemmas of Integrative Strategies for Urban and Electronic Spaces. University Of Newcastle, Australia.

27. Batten D (1995) Network Cities: Creative Urban Agglomerations for the 21st Century. Urban Studies 32: 313-327.
28. Townsend AM (2003) Wired/Unwired: The Urban Geography Of Digital Networks. Department of Urban Studies And Planning, Massachusetts Institute Of Technology, USA

29. Lemos A (2005) Cibercidades li. Ciberurbe: A Cidade Na Sociedade Da Informação. Editora E-Papers, Rio De Janeiro, Brazil.

30. Lefebvre H (1991) The Production Of Space. Wiley-Blackwell, Oxford, UK.

31. Barbero JM (1996) La Ciudad Virtual: Transformationes De La Sensibilidad Y Nuevos Escenarios De Comunicaión. Revista De La Universidad Del Valle, Cali, Columbia.

32. Castells M (2005) A Era Da Informação: Economia, Sociedade E Cultura Fundaçao Calouste Gulbenkian, Lisbon, Portugal 8.

33. Lévy P (1999) Cibercultura. Editora 34, São Paulo, Brazil.

34. Mendes LS, Bottoli ML, Breda GD (2009) Digital Cities and Open MANs: A New Communications Paradigm. IEEE Latin-American Conference On Communications 8: 1-8.

35. Rezende DA, Madeira GS, Mendes LS, Breda GD, Zarpelão BB, et al (2013) Information and Telecommunications Project for a Digital City: A Brazilian Case Study. Telematics and Informatics: In Press.

36. Nachmias D, Nachmias C (2008) Research Methods in the Social Sciences Worth Publishers, New York, USA.

37. Gil AC (2008) Métodos E Técnicas De Pesquisa Social. Atlas, São Paulo, Brazil.

38. Marconi MA, Lakatos EM (2008) Técnicas De Pesquisa. Atlas, São Paulo Brazil.

39. Roesch SMA (2005) Projeto De Estágio E De Pesquisa Em Administração: Guia Para Estágios, Trabalhos De Conclusão, Dissertação E Estudos De Caso. Atlas, São Paulo, Brazil.

40. Yin RK (2008) Case Study Research: Design and Methods. Sage Publications Inc, USA. 